\title{
Planlanmamış Gebeliklerin Doğum Sonrası Erken Dönemdeki Annelik Davranışına Etkisi
}

\section{Effects of Unplanned Pregnancies on Maternal Behavior in the Early Postpartum}

\section{Period}

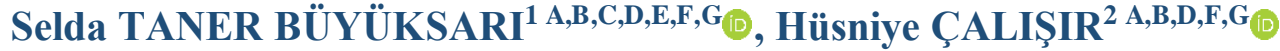 \\ ${ }^{1}$ Salihli Devlet Hastanesi, Salihli/Manisa, Türkiye \\ ${ }^{2}$ Aydın Adnan Menderes Üniversitesi Hemşirelik Fakültesi Çocuk Sağlığı ve Hastalıkları Hemşireliği Anabilim Dalı, Aydın, \\ Türkiye
}

ÖZ

\begin{abstract}
Amaç: Planlanmamış gebelikler, kadınlar, çocukları ve aileleri için istenmeyen ekonomik, psikolojik ve sosyal sonuçlar doğurabilir. Bu çalışma, planlamadan gebe kalmanın doğum sonrası erken dönemdeki ilk annelik davranışına etkisini ve etkileyen diğer faktörleri belirlemek amacıyla yapıldı.

Yöntem: Bu vaka kontrol çalışması Kasım 2012 ile Haziran 2013 arasında doğum yapan 348 kadın ile yapıldı. Çalışmaya katılmayı kabul eden kadınlar olasılıksız örnekleme yöntemine göre seçildi. Örneklem grubunu, planlamadan gebe kalan (vaka grubu) 174 kadın, planlayarak gebe kalan (kontrol grubu) 174 kadın olmak üzere toplam 348 kadın oluşturdu. Veriler, Doğum Sonrası Ebeveynlik Davranışı Ölçeği (DSEDÖ) kullanılarak doğum sonrası ilk 10 dakikada gözlem ve bir anket formu kullanarak ilk 24 saat içinde yüz yüze görüşme yöntemiyle toplandı.

Bulgular: Bu çalışmada planlamadan gebe kalan kadınlar ve planlayarak gebe kalan kadınların DSEDÖ puan ortalamaları sırasıyla, $2.01 \pm 1.24$ ve $5.18 \pm 0.79$ olarak bulundu. Planlamadan gebe kalan kadınların doğum sonrası erken dönemdeki annelik davranış puanları, planlayarak gebe kalan kadınların doğum sonrası erken dönemdeki annelik davranış puanlarından daha düşük bulundu $(\mathrm{p}<0.05)$. Çalışmada kadınların planlamadan gebe kalması, canlı doğum sayısının fazla olması, gelirin giderden az olması ve doğum öncesi bebek bakımı ile ilgili bilgi almamıș olması, DSEDÖ puanlarını olumsuz etkileyen faktörler olarak bulundu $(\mathrm{p}<0.05)$.

Sonuç: Planlanmayan gebeliklerin doğum sonrası erken dönemdeki annelik davranışlarına olumsuz etkisinin olduğu bulunmuştur. Ebe ve hemşireler tarafından kadınların doğum sonrası erken dönemdeki annelik davranışı ile ilişkili risk faktörlerinin bilinmesi, annelerin gereksinimlerinin belirlenmesi ve ebeveynliğe uyumlarının desteklenmesi açısından önemlidir.
\end{abstract}

Anahtar Kelimeler: Annelik davranışı, Doğum sonrası erken dönem, Ebelik, Hemşirelik, Planlanmamış gebelik.

\section{ABSTRACT}

Objective: Unplanned pregnancies can have adverse psychological, social, and economic consequences for women, their children and families. The purpose of this study was to determine the effects of unplanned pregnancies on maternal behavior in the early postpartum period.

Methods: This case-control study was performed on 348 women giving birth between November 2012 and June 2013. The women were selected through non-probability sampling among those accepting to participate in the study. The sample group consisted of a total of 348 women, including 174 women who conceived from the planning (case group) and 174 women who conceived by planning (control group). Data were collected with the Postpartum Parenting Behavior Scale (PPBS) through observations within the first ten minutes of births and a questionnaire form at face to face interviews within 24 hours of births. Results: The women with unplanned pregnancy and those with planned pregnancy got the mean scores of $2.01 \pm 1.24$ and 5.18 \pm 0.79 for the PPBS, respectively. The women with unplanned pregnancy received lower scores for maternal behavior in the

Sorumlu Yazar: Hüsniye ÇALIŞIR

Aydın Adnan Menderes Üniversitesi Hemşirelik Fakültesi, Çocuk Sağlığı ve Hastalıkları Hemşireliği Anabilim Dalı, Aydın, Türkiye calisirh@hotmail.com

*Bu çalışma Aydın Adnan Menderes Üniversitesi Sağlık Bilimleri Enstitüsü’nde, 2014 yılında yapılan yüksek lisans tezinden üretilmiş ve 10-12 Eylül 2015 tarihinde Erzurum'da düzenlenen 15. Ulusal Hemșirelik Kongresi'nde poster bildiri olarak yayımlanmıștır Geliş Tarihi: 23.03.2020 - Kabul Tarihi: 19.05.2020

Yazar Katkıları: A) Fikir/Kavram, B) Tasarım, C) Veri Toplama ve/veya İșleme, D) Analiz ve/veya Yorum, E) Literatür Taraması, F) Makale Yazımı, G) Eleştirel İnceleme 
early postpartum period $(\mathrm{p}<0.05)$. In the study, it was found that unplanned pregnancy, higher number of live births, lowerincome than expense, and obtaining information about baby care in the prenatal period, were the factors that negatively affect maternal behavior scores $(\mathrm{p}<0.05)$.

Conclusion: Unplanned pregnancies may affect the postpartum maternal behavior negatively. Midwives and nurses must be aware of risk factors related to postpartum maternal behavior so that mothers' needs can be identified and their adaptation to motherhood can be supported.

Key words: Early postpartum period, Maternal behavior, Midwifery, Nursing, Unplanned pregnancy.

\section{GíRiş}

Planlanmamış gebelikler hem gelişmiş hem de gelişmekte olan ülkelerde önemli bir halk sağlığı sorunudur. Dünya çapında, 2010-2014 yılları arasında gelişmekte olan ve gelişmiş̧ bölgelerdeki istenmeyen gebelik oranları arasındaki fark dikkat çekicidir: 2010-2014 döneminde, gelişmiş bölgelerde 15-44 yaş arası 1.000 kadının 45'i istemeden gebe kalırken, gelişmekte olan bölgelerde aynı yaş grubunda her 1000 kadından 65 ' $\mathrm{i}$ istemeden gebe kalmışıtır (1). Dünya'da 2012 yllında gerçekleşen 213 milyon gebeliğin \%40'1 - yaklaşı 85 milyonu istenmeyen gebeliktir. Bunların \%50'si kürtajla, \%13'ü düşükle sonuçlanmış ve \%38'i planlanmamış doğum olarak gerçekleşmiştir (2). Farklı yıllarda yapılan çalışmalarda planlanmamış gebelik sıklığı İngiltere'de \%16.2 (3), Etiopya'da \%29.9 (4) olarak bulunmuştur. Planlanmamış gebeliklerin oranı diğer ülkelerde olduğu gibi ülkemizde de az değildir. Türkiye Nüfus ve Sağlık Araştırması 2013 sonuçlarına göre Türkiye'de son beş yıl içindeki doğumların $\% 74$ 'ü istenen zamanda gerçekleşirken, \%11.2'sinin daha sonra olması tercih edilmiş ve \%12.5'i de hiç istenmemiştir. Sonuç olarak bu doğumların yaklaşı \%24'ü planlanmamış gebelik (gebe kalmayı istememe veya daha sonra isteme) sonucu gerçekleşmiş̧ir (5). Beş yıl sonra yapılan 2018 Türkiye Nüfus Sağlık Araştırması'nda da benzer sonuçlar elde edilmiş; gerçekleşen doğumların ve devam eden gebeliklerin \% 75 ' inin isteyerek gerçekleştĭgi, \%11'inin daha sonra olmasının tercih edildiği ve \%15'inin de istenmediği saptanmıştır (6). Türkiye'de yapılan farklı bölgesel çalışmalarda ise planlanmamış gebelik oranları \%27.1 (7) ve \%23.2 (8) olarak bulunmuştur.

Planlanmamış gebelik, istenen zamandan önce gerçekleşen ya da daha sonra olması tercih edilen veya hiç istenmeyen gebelik şeklinde tanımlanır. Planlanmamış gebelikler, gebeliği önleyici hiçbir yöntem kullanılmaması, yöntemin düzensiz ya da hatalı kullanımı ya da yöntem başarısızlıkları nedeni ile meydana gelmektedir (5). Planlanmamış gebelikler bütün yaş grupları ve sosyo-ekonomik düzeyde görülebilir. Planlanmamış gebelikler, kadınlar, onların çocukları ve aileleri için ekonomik, psikolojik ve sosyal sonuçlar doğurabilir. Gebeliğin planlanmadan gerçekleşmesi bu olumsuz sonuçlarının yanında anne ve çocuk sağlığını da olumsuz etkilemektedir (4,9-11). Planlanmamış gebelikler, istenmeyen doğum veya kürtajla sonuçlanabilir; bu da annelerin gebelik ve doğumunu etkileyebilir, morbidite ve mortalite riskini arttırabilir, anne bebek ilişkisinin kalitesini düşürebilir. Planlanmamış gebelikler sonucunda doğan çocuklarda düşük doğum ağırlığı ve gelişim yetersizliği riski artabilir $(4,11)$

Anneliğe hazırlanmış, bebeğini isteyerek doğurmuş, bebeğin ihtiyaçlarını anlayan ve karşılayan anne bebeğiyle daha olumlu bir ilişki kurabilir $(10,12)$. Gebe kalma ya da anne-baba olma, bireylerin isteği dışında ve plansız gerçekleştiği zaman gebelik ve ebeveynlik rolüne uyumları daha güç olmaktadır. Plansız gebe kalan kadınlar, bağlanma gerçekleştikten sonra bebeklerini sevebilirler, fakat planlı gebe kalan kadınlara göre doğum sonrası kriz yaşama 
olasılı̆̆ı daha yüksektir (13). Yapılan bir çalışmada planlamadan gebe kalan kadınlar ile bebekleri arasındaki etkileşimin, planlayarak gebe kalan kadınlarınkinden daha yetersiz olduğu bulunmuştur. Ayrıca planlamadan gebe kalan kadınların doğum sonrasında bebeklerini emzirmede sorun yaşadıkları gösterilmiştir (10).

Doğumdan sonraki ilk karşılaşmada annenin bebeğine karşı gösterdiği davranışlar ilk annelik davranışı olarak kabul edilmektedir $(14,15)$. Anne doğumdan sonra bebeğiyle ilk defa karşılaştığında bebeğin yüzünü, ellerini ve vücudunun diğer bölümlerini inceler, bebekle göz teması kurmaya çalışır ve onunla konuşur. Annenin yüz yüze pozisyondayken bebeğine bakma, bebeğin elbiselerini giydirme-çıkarma, ona dokunma, gülümseme, konuşma, öpme, kucaklama, avutma ve sallama gibi davranışlarını gözleme, bağlanma sürecini anlamada yardımcı olabilir. Doğum sonrası ilk günlerde annelerin yenidoğan bebeklerini olumlu algılamaları, daha sonraki dönemlerde olumlu anne-bebek ilişkisini etkileyebilir $(15,16)$. Bu da yenidoğanın yaşamını fiziksel, ruhsal ve duygusal olarak sağlıklı bir şekilde sürdürmesine zemin hazırlar.

Doğum sonrası erken dönemde gebeliğin planlanmamış olması ile olumsuz annelik davranışı arasında ilişki olup olmadığının bilinmesi önemlidir. Ülkemizde ve yurt dışında planlanmamış gebeliklerin doğum sonrası erken dönemdeki annelik davranışına etkisinin araştırıldığı çalışmaya rastlanmadı. Bu çalışma, planlamadan gebe kalmanın doğum sonrası erken dönemdeki ilk annelik davranışına etkisini ve annelik davranışını etkileyen diğer faktörleri belirlemek amaciyla yapıldı.

Araştırma Soruları:

1.Planlamadan gebe kalan kadınların, doğum sonrası erken dönemde bebeğiyle ilk karşılaşmada annelik davranışı puanı ile planlayarak gebe kalan kadınların annelik davranışı puanı arasında fark var midır?

2.Gebeliğin planlı olup olmaması dışında kadınların doğum sonrası erken dönemdeki ilk annelik davranışı puanına etki eden başka faktörler var mıdır?

\section{GEREÇ VE YÖNTEMLER}

\section{Araştırmanın tipi}

$\mathrm{Bu}$ çalışma bir vaka-kontrol çalışmasıdır. Vaka grubu, planlamadan gebe kalmış kadınlardan, kontrol grubu ise planlayarak gebe kalmış kadınlardan oluştu.

\section{Araştırmanın yeri ve zamanı}

Araştırma Kasım 2012 ve Haziran 2013 tarihleri arasında, Türkiye'nin batısında yer alan iki devlet hastanesine doğum yapmak için yatan ve olasılıksız örnekleme yöntemlerinden uygun örnekleme yöntemi ile seçilen kadınlarla yapıldı. Örneklem büyüklüğü G-Power yazılımı kullanılarak tahmin edildi. Araştırmanın gücü, doğum yapan kadınların erken ebeveynlik davranışı ile ilgili ülkemizde yapılan bir çalışmadan elde edilen bulguya dayanarak hesapland1 (17). Buna göre yapılan güç analizinde etki büyüklüğü $=0.50 ; \alpha=0.05$ ve $\% 80$ güç alınarak yapılan hesaplamada her bir gruba alınacak kadın sayısı en az 174 olarak belirlendi. Vaka grubuna planlamadan gebe kalan ve kontrol grubuna planlayarak gebe kalan kadınlar alındı. Planlamadan gebe kalma, gebeliğin istenen zamandan önce gerçekleşmiş olması ya da daha sonra olması tercih edilen bir gebelik olması veya hiç istenmeyen bir gebelik olması 
şeklinde tanımlandı. Planlayarak gebe kalma, gebe kalmadan önce gebeliğin istenen zamanda gerçekleşmiş veya istenen bir gebelik olması şeklinde tanımlandı (5).

$\mathrm{Bu}$ çalışmada kadınlar için dahil etme kriterleri; 18-35 yaş arasında, en az ilkokul mezunu olma, vajinal yolla doğum yapmış olma, daha önceki gebeliklerinde düşük, bebek kaybı veya ölü doğum yapmamış olma idi. Bebekler için dahil etme kriterlerini ise miadında (37-42 haftalık), tekil, 2500-4000 gram ağırlığında doğmuş olma ve doğumsal anomalisi olmama oluşturdu. Katıldıktan sonra araştırmadan ayrılmak isteyen, veri toplama tamamlanmadan hastaneden taburcu olan, doğumdan sonra erken dönemde kendisi ve bebeğinde akut bir sağlık sorunu gelişen kadınlar araştırmadan çıkarıldı.

Veri toplama sürecinde toplam 370 kadın (183 vaka grubu; 187 kontrol grubu) çalışmaya davet edildi. Kontrol grubundan altı ve vaka grubundan dört kadın, eşi ya da diğer aile üyelerinin istemediği gerekçesiyle çalışmaya katılmayı kabul etmedi. Çalışmaya katılmayı kabul eden kontrol grubundan beş ve vaka grubundan iki kadın eşi ya da diğer aile üyelerinin istemediğini bildirerek çalışmadan ayrıldı. Çalışmaya katılmayı kabul eden kontrol grubundan iki, vaka grubundan üç kadın ise sağlık problemleri ve başka sebeplerle hastaneden erken ayrıldığ 1 ve veri toplama aşamaları tamamlanamadığ 1 için çalışmadan çıkarıldı. Sonuçta araştırmanın örneklemini toplam 348 kadın (Vaka grubu=174; Kontrol grubu=174) oluşturdu (Şekil 1).

\section{Veri Toplama Araçları}

Veriler, anket formu ve Doğum Sonrası Ebeveynlik Davranışı Ölçeği (DSEDÖ) ile toplandı. Anket formu, araştırmacılar tarafından hazırland1 $(16,17)$. Formda, kadınların sosyodemografik özelliklerinin ve araştırmanın diğer bağımsız verilerinin sorgulandığı 20 soru yer aldı. Bu formda kadınların ve eşlerinin yaş, eğitim düzeyi, çalışma durumu, evlilik yılı, aile tipi, sağlık güvencesi, gelir düzeyi gibi bazı sosyo-demografik özellikleri, gebelik ve doğum sürecine ilişkin veriler (gebelikte problem yaşama, doğum ve bebek bakımı hakkında bilgi) ve bebeklerin özelliklerini (cinsiyeti ve doğum ağırlı̆̆ı) içeren sorular yer aldı. Form, 15 kadına ön uygulama yapılarak denendi ve anlaşılması zor olan bir soru daha anlaşılır şekilde yeniden düzenlendi.

Doğum Sonrası Ebeveynlik Davranışı Ölçeği (DSEDÖ) İngilizce adı The Postpartum Parenting Behavior Scale (PPBS) olan ölçek, doğumdan sonra anne-babanın bebeğiyle ilk karşılaşması sırasında bebeğe karşı gösterdikleri ebeveynlik davranışını değerlendirmek amacıyla Britton ve arkadaşları (18) tarafından geliştirilmiştir. Ölçek anne-babalara sadece doğumdan sonraki ilk dakikalarda uygulanabilir. Ölçeğin, Türkçe’ye uyarlanması, geçerlik ve güvenirliği yapılmıştır (15). Ölçeğin Türkçe formu altı maddeden oluşmaktadır. Bu maddeler var/yok şeklinde işaretlenerek ikili puanlama yapılır; ölçekten en az 0, en yüksek 6 puan değeri elde edilir. Gözlemciler arası tutarlılık katsayısı toplam puan için 0.97'dir ve güvenilirlik katsayısı 0.80 ile 0.83 arasında değişmektedir (15). Bu çalışmada ölçeğin güvenirlik katsayısı $\alpha=0.78$ olarak bulundu. 


\section{Verilerin Toplanması}

Veriler,gözlem ve yüz yüze görüşme yöntemleriyle toplandı. İlk önce doğum salonlarına gidilerek planlamadan ve planlayarak gebe kalan kadınlar tespit edildi. Doğumdan sonra anne bebeğiyle buluşturularak 10 dakika beraber olmaları sağlandı. Bebeğine gösterdiği davranışlar gözlenerek DSEDÖ'ye kaydedildi. Annenin bebeğini emzirmesi sağlandı ve doğum sonrası bakımları yapıldı. Taburcu olmadan önce, yüz yüze görüşme yöntemiyle anket formu dolduruldu.

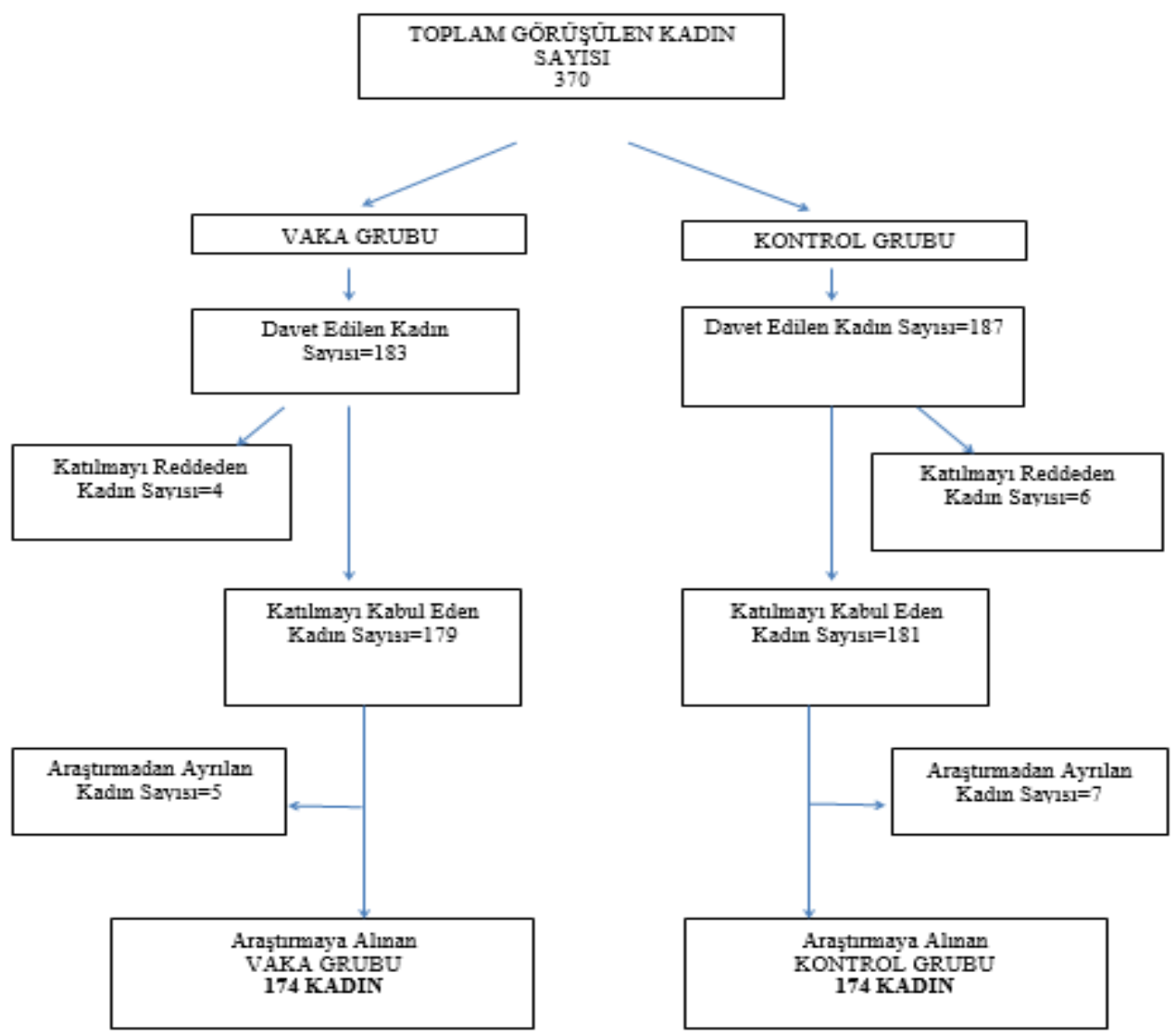

Şekil 1. Vaka ve Kontrol Grubundaki Kadınların Örnekleme Alınma Süreci

\section{Araştırmanın Etik Yönü}

Adnan Menderes Üniversitesi Tıp Fakültesi Girişimsel Olmayan Klinik Araştırmalar Etik Kurulu Başkanlığı'ndan, yapılan araştırmanın etik ilkelere uygun olduğuna ilişkin onay alınd1 (Protokol no: 2012/93). Araştırmanın yapıldığı hastanelerin yönetimlerinden yazılı izin alındı. Kadınlara araştırma amaç ve yöntemi hakkında açıklama yapıldıktan sonra katılmayı kabul eden kadınlardan yazılı onam alındı.

\section{Veri analizi}

Araştırmanın verileri PASW Windows 18.0 (SPSS, Chicago, IL) programı ile analiz edildi. Veriler tanımlayıcı istatistikler, ki-kare testi ve gruplar arasındaki farkın hangi gruptan kaynaklandığını belirlemek için ileri ki-kare testi kullanıldı. Örneklem grubunun DSEDÖ toplam puanlarına göre normal dağılıma uyup uymadığını değerlendirmek için Kolmogorov 
Smirnov testi kullanıldı. Örneklem grubunun DSEDÖ puanlarının dağılımı normal dağılıma uymadığı $(\mathrm{p}<0.001)$ için ikiden fazla bağımsız grup arasındaki farkın karşılaştırılmasında Kruskal-Wallis testi ve iki grup karşılaştırılmasında Mann Whitney U testi uygulandı. $\mathrm{P}<0.05$ düzeyindeki değerler istatistiksel olarak önemli kabul edildi.

Bu çalışmada vaka ve kontrol gruplarının, kadının yaşı, evlilik yılı, eğitim düzeyi, aile tipi, gelir düzeyi, canlı doğum sayısı, gebelikte problem yaşama durumu, doğum öncesi bebek bakımıyla ilgili bilgi alma durumu, eşin yaşı, eşin eğitim düzeyi ve eşin çalışma durumu bakımından homojen olmadığı için yukarıdaki değişkenlerin doğum sonrası erken dönemdeki annelik davranışını etkileyen önemli karıştırıcı faktörler olduğu düşünüldü. $\mathrm{Bu}$ nedenle gebeliğin planlanmış ya da planlanmamış olması dışındaki diğer bağımsız değişkenlerin DSEDÖ puanına etkisini belirlemek için çoklu linear regresyon analizi uygulandı. Bağımsız değişkenler arasında yüksek korelasyon olduğunda değişkenlerin benzer bilgiler sağ layacağ 1 ve her bir değişkenin etkisini ayırmanın zorlaşacağı belirtilmektedir (19). Burns ve Grove (20), değişkenler arasında 0.65 'in üzerinde korelasyon bulunması durumunda çoklu bağlantının oluştuğundan bahsetmektedirler. Bu nedenle modele alınacak bağımsız değişkenler arasında doğrusal çoklu bağlantı test edildi. Bağımsız değişkenler arasında doğrusal çoklu bağlantı olup olmadığını test etmek için Pearson korelasyon testi ve Spearman korelasyon testi kullanıldı. Kadının yaşı ile evlilik yılı arasında $(\mathrm{r}=0.71 ; \mathrm{p}<0.001)$ yüksek korelasyon, kadının yaşı ile eşinin yaşı arasında $(r=0.91 ; p<0.001)$ ve kadının eğitim düzeyi ile eşinin eğitim düzeyi arasında $(\mathrm{r}=0.92 ; \mathrm{p}<0.001)$ çok yüksek korelasyon bulundu. Birbiriyle yüksek ve çok yüksek korelasyon gösteren bu değişkenlerden evlilik yılı, eşin yaşı ve eşin eğitim düzeyi, grupları DSEDÖ puanları bakımından karşılaştırma ve çoklu linear regresyon analizine alınmadı. Sonuçta, gebeliğin planlanmış olma durumu, canlı doğum sayısı, kadının yaşı, kadının eğitim düzeyi, eşin çalışma durumu, aile tipi, gelir düzeyi, gebelikte problem yaşama durumu ve doğum öncesi bebek bakımıyla ilgili bilgi alma durumu modele alındı. Doğum Sonrası Ebeveynlik Davranışı araştırmanın bağımlı değişkenidir. Araştırmanın ana bağımsız değişkeni gebeliğin planlı olup olmamasıdır. Diğer bağımsız değişkenleri ise kadınların yaşı, eğitim düzeyi, çalışma durumu, eşin çalışma durumu, sağlık güvencesi, aile tipi, gelir düzeyi gibi bazı sosyo-demografik özellikleri, gebelik ve doğum sürecine ilişkin veriler (gebelikte problem yaşama, doğum ve bebek bakımı hakkında bilgilenme) ve bebeklerin özelliklerini (cinsiyeti ve doğum ağırlığı) içeren veriler oluşturdu.

\section{BULGULAR}

Bu çalışma, planlamadan gebe kalan (vaka) 174; planlayarak gebe kalan (kontrol) 174 olmak üzere toplam 348 kadın ile yapıldı.

\section{Sosyo-demografik özellikler}

Vaka grubundaki kadınların yaş ortalaması $24.45 \pm 5.08$ yıl ve kontrol grubundaki kadınların yaş ortalaması $27.20 \pm 4.26$ yıl idi. Tablo 1 'de araştırmaya katılan kadınların ve eşlerinin bazı sosyo-demografik özellikleri gösterildi. İki grubun yaş grupları dağılımı bakımından benzer olmadığı $(\mathrm{p}<0.001)$ ve yapılan ileri ki-kare analizinde bu farkın 19-29 yaş ile 30-35 yaş grupları arasındaki farktan kaynaklandığı saptandı $(\mathrm{p}<0.001)$. Vaka ve kontrol 
grupları arasında evlilik yılına göre istatistiksel olarak anlamlı fark vardı $(p<0.001)$. Vaka grubunda 11-20 yıldır evli olan kadınların oranı kontrol grubuna göre daha fazlaydı $(\mathrm{p}<0.001)$.

İki grubun eğitim düzeyleri bakımından benzer olmadığı $(\mathrm{p}=0.016)$ ve vaka grubunda ilkokul mezunu kadınların oranının, lise veya üniversite mezunu kadınların oranından daha fazla olduğu saptandı $(\mathrm{p}=0.004)$. Vaka ve kontrol grubundaki kadınların eşlerinin çalışma durumlarına $(\mathrm{p}=0.001)$, aile tipine $(\mathrm{p}=0.005)$ ve algılanan gelir düzeyine $(\mathrm{p}<0.001)$ göre benzer olmadığ1 saptandı. Araştırmada iki grubun yalnızca sosyal güvence ve çalışma durumlarına göre benzer olduğu saptandı (Tablo 1).

Tablo 1. Kadınların ve Eşlerinin Bazı Sosyo-demografik Özelliklerine Göre Dağılımı (N=348)

\begin{tabular}{|c|c|c|c|c|}
\hline Özellikler & Vaka grubu $(n=174)$ & Kontrol grubu (n=174) & $\chi^{2}$ & $\mathbf{p}$ \\
\hline \multicolumn{5}{|l|}{ Yaş grubu } \\
\hline $18-19$ yaş & $27(15.5)$ & $3(1.7)$ & \multirow{3}{*}{23.458} & \multirow{3}{*}{$<0.001$} \\
\hline $20-29$ yaş & $113(65.0)$ & $118(67.8)$ & & \\
\hline $30-35$ yaş & $34(19.5)$ & $53(30.5)$ & & \\
\hline \multicolumn{5}{|l|}{ Eş yaş grubu } \\
\hline $19-29$ yaş & $122(70.1)$ & $94(54.0)$ & \multirow{3}{*}{13.783} & \multirow{3}{*}{0.001} \\
\hline $30-35$ yaş & $27(15.5)$ & $56(32.2)$ & & \\
\hline $36-44$ yaş & $25(14.4)$ & $24(13.8)$ & & \\
\hline \multicolumn{5}{|l|}{ Evlilik yılı } \\
\hline $1-5$ y1l & $118(67.8)$ & $134(77.0)$ & \multirow{3}{*}{25.027} & \multirow{3}{*}{$<0.001$} \\
\hline $6-10$ y1l & $26(14.9)$ & $37(21.3)$ & & \\
\hline $11-20$ y1l & $30(17.2)$ & $3(1.7)$ & & \\
\hline \multicolumn{5}{|l|}{ Eğitim düzeyi } \\
\hline İlkokul & $108(62.1)$ & $90(51.7)$ & \multirow{3}{*}{8.211} & \multirow{3}{*}{0.016} \\
\hline Ortaokul & $48(27.6)$ & $47(27.0)$ & & \\
\hline Lise / Üniversite* & $18(10.3)$ & $37(21.3)$ & & \\
\hline \multicolumn{5}{|l|}{ Eş eğitim düzeyi } \\
\hline İlkokul & $98(56.3)$ & 81 (46.6) & \multirow{3}{*}{9.191} & \multirow{3}{*}{0.010} \\
\hline Ortaokul & $54(31.1)$ & $49(28.2)$ & & \\
\hline Lise/Üniversite* & $22(12.6)$ & $44(25.3)$ & & \\
\hline \multicolumn{5}{|l|}{ Çalışma durumu } \\
\hline Çalışıyor & $9(5.2)$ & $19(10.9)$ & \multirow[t]{2}{*}{3.884} & \multirow[t]{2}{*}{0.076} \\
\hline Çalışmıyor & $165(94.8)$ & $155(89.1)$ & & \\
\hline \multicolumn{5}{|l|}{ Eş çalışma durumu } \\
\hline Çalıșiyor & $152(87.4)$ & $170(97.7)$ & \multirow[t]{2}{*}{13.468} & \multirow[t]{2}{*}{0.001} \\
\hline Çalışmıyor & $22(12.6)$ & $4(2.3)$ & & \\
\hline \multicolumn{5}{|l|}{ Aile tipi } \\
\hline Geniş aile & $30(17.2)$ & $12(6.9)$ & \multirow[t]{2}{*}{8.773} & \multirow[t]{2}{*}{$0.005^{* *}$} \\
\hline Çekirdek aile & $144(82.8)$ & $162(93.1)$ & & \\
\hline \multicolumn{5}{|l|}{ Sosyal güvence } \\
\hline Olanlar & $161(92.5)$ & $164(94.3)$ & \multirow[t]{2}{*}{0.419} & $0.666 * *$ \\
\hline Olmayanlar & $13(7.5)$ & $10(5.7)$ & & \\
\hline Algılanan gelir düzeyi & & & & \\
\hline Gelir giderden az & $106(60.9)$ & $11(6.3)$ & 116.206 & $<0.001$ \\
\hline Gelir gidere eşit /fazla & $68(39.1)$ & $163(93.7)$ & & \\
\hline
\end{tabular}

*Kontrol grubundaki lise/üniversite mezunu grubunda yer alan kadınların 6's1 üniversite mezunudur. Vaka grubunda lise/üniversite mezunu grubunda yer alan eşlerin 5'i, kontrol grubundaki eşlerin7'si üniversite mezunudur.

**Gözlerde beklenen değerler 5-25 arasında olduğu için Yates-düzeltmeli ki-kare analizi yapıldı.

\section{Kadınların gebelik, doğum ve bebeklerinin özellikleri}

Tablo 2'de kadınların gebelik, doğum ve bebeklerinin özelliklerine göre dağılımı gösterildi. Araştırmada kontrol grubundaki kadınların içinde ilk doğumunu yapanların oranı, 
vaka grubuna göre daha fazlayd $1(\mathrm{p}<0.001)$. Vaka grubundaki kadınlar, kontrol grubundakilere göre gebelikte daha fazla problem yaşadıklarını ifade ettiler $(\mathrm{p}<0.001)$. Doğum öncesi bebek bakımı konusunda bilgi alma durumuna göre iki grup arasında fark vardı $(p<0.001)$. Araştırmada bebeklerin cinsiyeti ve doğum kilolarına göre iki grup benzerdi ( $p>0.05)$.

Tablo 2. Kadınların Gebelik, Doğum ve Bebeklerinin Özelliklerine Göre Dağılımı (N=348)

\begin{tabular}{|c|c|c|c|c|}
\hline Özellikler & $\begin{array}{c}\text { Vaka grubu }(\mathrm{n}=174) \\
\mathrm{n}(\%)\end{array}$ & $\begin{array}{c}\text { Kontrol grubu }(\mathrm{n}=174) \\
\mathrm{n}(\%)\end{array}$ & $\chi^{2}$ & $\mathbf{p}$ \\
\hline \multicolumn{5}{|l|}{ Doğum sayısı } \\
\hline İlk doğum & $74(42.5)$ & $124(71.3)$ & 29.293 & $<0.001$ \\
\hline $2-8$ doğum & $100(57.5)$ & $50(28.7)$ & & \\
\hline \multicolumn{5}{|c|}{$\begin{array}{l}\text { Gebelikte problem } \\
\text { yaşama }\end{array}$} \\
\hline Yaşayan & $47(27.0)$ & $18(10.3)$ & 15.910 & $<0.001$ \\
\hline Yaşamayan & $127(73.0)$ & $156(89.7)$ & & \\
\hline \multicolumn{5}{|c|}{ Bebek bakımıyla ilgili } \\
\hline bilgi alma & & & & \\
\hline Bilgi alan & $102(58.6)$ & $138(79.3)$ & 17.400 & $<0.001$ \\
\hline Bilgi almayan & $72(41.4)$ & $36(20.7)$ & & \\
\hline \multicolumn{5}{|c|}{ Bebeğin cinsiyeti } \\
\hline $\mathrm{K} 1 \mathrm{z}$ & $93(53.4)$ & $93(53.4)$ & 0.000 & 1.000 \\
\hline Erkek & $81(46.6)$ & $81(46.6)$ & & \\
\hline \multicolumn{5}{|c|}{ Bebeğin doğum ağırlığı } \\
\hline $2500-2999 \mathrm{gr}$ & $41(23.6)$ & $39(22.4)$ & & \\
\hline $3000-3499 \mathrm{gr}$ & $67(38.5)$ & $82(47.1)$ & 2.980 & .225 \\
\hline $3500-4000 \mathrm{gr}$ & $66(37.9)$ & $53(30.5)$ & & \\
\hline
\end{tabular}

\section{Kadınların DSEDÖ puanları ve etkileyen faktörler}

Araştırmaya katılan vaka grubundaki kadınların DSEDÖ puan ortalaması 2.01 \pm 1.24 iken, kontrol grubundaki kadınların DSEDÖ puan ortalaması 5.18 \pm 0.79 olarak saptand1. Yapılan istatistiksel analizde, vaka ve kontrol gruplarının DSEDÖ puan ortalamaları arasındaki farkın önemli olduğu saptandı $(\mathrm{p}<0.001)$. Buna göre vaka grubundaki kadınların DSEDÖ puan ortalamaları, önemli bir farkla kontrol grubundaki kadınların ortalamalarından düşüktü (Tablo $3)$.

Tablo 3. Vaka ve Kontrol Gurubundaki Kadınların DSEDÖ Puan Ortalamaları (N=348)

\begin{tabular}{lcccc}
\hline & Vaka grubu $(\mathbf{n = 1 7 4})$ & Kontrol grubu $(\mathbf{n = 1 7 4 )}$ & & \\
\cline { 2 - 4 } & $\begin{array}{c}\text { Ortalama } \pm \text { SS } \\
(\text { Ortanca, alt-üst) }\end{array}$ & $\begin{array}{c}\text { Ortalama } \pm \text { SS } \\
\text { (Ortanca, alt-üst) }\end{array}$ & & p \\
\hline \multirow{2}{*}{ DSEDÖ puanı } & $2.01 \pm 1.24$ & $5.18 \pm 0.79$ & -15.259 & $<0.001$ \\
\hline
\end{tabular}

Araştırmaya katılan kadınların bazı sosyo-demografik ve doğuma ilişkin özelliklerine göre DSEDÖ puan ortalamaları karşılaştırıldı (Tablo 4). Yaş gruplarına göre kadınların DSEDÖ puan ortalamaları arasında fark olduğu $(\mathrm{p}=0.005), 18-19$ yaş grubundaki kadınların DSEDÖ puan ortalamalarının, daha büyük yaş gruplarındaki kadınların DSEDÖ puan ortalamalarından daha düşük olduğu saptandı. Araştırmada eğitim düzeyi yüksek olan kadınların daha düşük eğitim düzeyindeki kadınlara göre $(p<0.001)$, eşleri çalışan kadınların eşleri çalışmayanlara göre $(\mathrm{p}<0.001)$, çekirdek ailede yaşayanların kadınların geniş ailede yaşayanlara göre $(\mathrm{p}=0.019)$ DSEDÖ puan ortalamaları daha yüksekti (Tablo 4). 
Gelirleri giderlerine eşit ya da fazla olan kadınların geliri giderinden az olan kadınlara göre ( $p<0.001)$, ilk doğumunu yapan kadınların iki ve daha fazla doğum yapanlara göre $(p<0.001)$, gebelikte problem yaşamayanların problem yaşayanlara göre $(\mathrm{p}<0.001)$ ve doğum öncesi bebek bakımıla ilgili bilgi alan kadınların bilgi almayanlara göre $(\mathrm{p}<0.001)$ DSEDÖ puan ortalamaları daha yüksekti (Tablo 4).

Tablo 4. Kadınların Bazı Sosyo-demografik ve Doğuma İlişkin Özelliklerine Göre DSEDÖ Puan Ortalamalarının Karşılaştırılması $(\mathrm{N}=348)$

\begin{tabular}{|c|c|c|c|c|c|}
\hline \multirow{2}{*}{ Özellikler } & & \multicolumn{2}{|c|}{ DSEDÖ Puanı } & \multirow{2}{*}{$\chi^{2} \mathrm{KW} / \mathrm{Z}$} & \multirow{2}{*}{ p-değeri } \\
\hline & & Ortalama \pm SS & Ortanca (alt-üst) & & \\
\hline Yaş grubu & $\begin{array}{l}18-19 \text { yaş } \\
20-29 \text { yaş } \\
30-35 \text { yaş }\end{array}$ & $\begin{array}{l}2.53 \pm 1.45 \\
3.68 \pm 1.86 \\
3.76 \pm 2.02\end{array}$ & $\begin{array}{l}2.00(0-6) \\
4.00(0-6) \\
4.00(0-6)\end{array}$ & $\chi^{2} \mathrm{KW}=10.517$ & 0.005 \\
\hline Eğitim düzeyi & $\begin{array}{l}\text { İlkokul } \\
\text { Ortaokul } \\
\text { Lise/Üniversite }\end{array}$ & $\begin{array}{l}3.30 \pm 1.95 \\
3.61 \pm 1.71 \\
4.64 \pm 1.61\end{array}$ & $\begin{array}{l}3.00(0-6) \\
4.00(1-6) \\
5.00(1-6)\end{array}$ & $\chi_{\mathrm{KW}}^{2}=23.617$ & $<0.001$ \\
\hline $\begin{array}{l}\text { Eşin çalışma } \\
\text { durumu }\end{array}$ & $\begin{array}{l}\text { Çalışıyor } \\
\text { Çalışmıyor }\end{array}$ & $\begin{array}{l}3.71 \pm 1.87 \\
2.19 \pm 1.65\end{array}$ & $\begin{array}{l}4.00(0-6) \\
2.00(0-6)\end{array}$ & $Z=-3.824$ & $<0.001$ \\
\hline Aile tipi & $\begin{array}{l}\text { Geniş aile } \\
\text { Çekirdek aile }\end{array}$ & $\begin{array}{l}2.98 \pm 1.71 \\
3.68 \pm 1.90\end{array}$ & $\begin{array}{l}3.00(0-6) \\
4.00(0-6)\end{array}$ & $Z=-2.339$ & 0.019 \\
\hline $\begin{array}{l}\text { Algılanan gelir } \\
\text { düzeyi }\end{array}$ & $\begin{array}{l}\text { Gelir giderden az } \\
\text { Gelir gidere } \\
\text { eşit/fazla }\end{array}$ & $\begin{array}{l}2.01 \pm 1.57 \\
4.40 \pm 1.49\end{array}$ & $\begin{array}{l}2.00(0-6) \\
5.00(1-6)\end{array}$ & $Z=-10.718$ & $<0.001$ \\
\hline Doğum sayısı & $\begin{array}{l}\text { Ilk doğum } \\
2-8 \text { doğum }\end{array}$ & $\begin{array}{l}4.19 \pm 1.70 \\
2.81 \pm 1.86\end{array}$ & $\begin{array}{l}5.00(0-6) \\
2.00(0-6)\end{array}$ & $Z=-6.674$ & $<0.001$ \\
\hline $\begin{array}{l}\text { Gebelikte problem } \\
\text { yaşama }\end{array}$ & $\begin{array}{l}\text { Yaşayan } \\
\text { Yaşamayan }\end{array}$ & $\begin{array}{l}2.71 \pm 2.00 \\
3.80 \pm 1.81\end{array}$ & $\begin{array}{l}2.00(0-6) \\
4.00(0-6)\end{array}$ & $Z=-3.960$ & $<0.001$ \\
\hline $\begin{array}{l}\text { Bebek bakımıyla } \\
\text { ilgili bilgi alma }\end{array}$ & $\begin{array}{l}\text { Bilgi alan } \\
\text { Bilgi almayan }\end{array}$ & $\begin{array}{l}4.03 \pm 1.75 \\
2.63 \pm 1.84\end{array}$ & $\begin{array}{l}5.00(0-6) \\
2.00(0-6)\end{array}$ & $Z=-6.463$ & $<0.001$ \\
\hline
\end{tabular}

Tablo 5'de kadınların DSEDÖ puanları ile sosyo-demografik, gebelik ve doğuma ilişkin faktörlerin ilişkisi gösterildi. Yapılan çoklu linear regresyon analizinde gebeliğin planlanma durumu, canlı doğum sayısı, kadının yaşı, eğitim düzeyi, eşin çalışma durumu, aile tipi, gelir düzeyi, gebelikte problem yaşama ve doğum öncesi bebek bakımı ile ilgili bilgi alma durumunun kadınların DSEDÖ puanıyla ilişkisi test edildi. Buna göre diğer faktörler kontrol altına alındıktan sonra gebeliğin planlanma durumunun $(\mathrm{p}<0.001)$, canlı doğum sayısının $(\mathrm{p}=0.002)$, gelir düzeyinin $(\mathrm{p}=0.001)$ ve doğum öncesi bebek bakımı ile ilgili bilgi alma durumunun ( $\mathrm{p}=0.002)$ kadınların DSEDÖ puanını etkileyen faktörler olduğu saptandı. 
Tablo 5. Kadınların DSEDÖ Puanları ile İlişkili Faktörler (N=348)

\begin{tabular}{|c|c|c|c|c|c|}
\hline \multirow[b]{2}{*}{ İlişkili Faktörler } & \multirow[b]{2}{*}{$\boldsymbol{\beta}$} & \multirow[b]{2}{*}{ SE } & \multirow[b]{2}{*}{$\mathbf{t}$} & \multirow[b]{2}{*}{$\mathbf{p}$} & $(95 \% \mathrm{CI})$ \\
\hline & & & & & Alt, Üst \\
\hline (Constant) & 4.501 & 0.429 & 10.480 & $<0.001$ & $3.656,5.346$ \\
\hline $\begin{array}{l}\text { Gebeliğin planlanmamış } \\
\text { olması* }\end{array}$ & -2.535 & 0.149 & -16.965 & $<0.001$ & $-2.829,-2.241$ \\
\hline Canlı doğum sayısı & -0.239 & 0.077 & -3.097 & 0.002 & $-0.392,-0.087$ \\
\hline Kadının yaşı & 0.014 & 0.015 & 0.938 & 0.349 & $-0.015,0.043$ \\
\hline İlkokul mezunu olma * & -0.124 & 0.110 & -1.124 & 0.262 & $-0.340,0.093$ \\
\hline Eşin çalışmaması* & 0.408 & 0.213 & 1.914 & 0.056 & $-0.011,0.828$ \\
\hline Geniş aile* & 0.026 & 0.180 & 0.145 & 0.885 & $-0.328,0.380$ \\
\hline Gelirin giderden az olması* & -0.473 & 0.141 & -3.362 & 0.001 & $-0.750,-0.196$ \\
\hline Gebelikte problem yaşama * & -0.070 & 0.139 & -0.507 & 0.612 & $-0.344,0.203$ \\
\hline $\begin{array}{l}\text { Bebek bakımı konusunda } \\
\text { bilgi alma* }\end{array}$ & 0.398 & 0.129 & 3.092 & 0.002 & $0.145,0.651$ \\
\hline
\end{tabular}

\section{TARTIŞMA}

Bu çalışmada, kadınların doğum sonrası erken dönemde bebekleriyle ilk karşılaşmada bebeklerine karşı gösterdikleri ebeveynlik davranışlarına ilişkin bulgular incelendiğinde, planlamadan gebe kalan kadınların ebeveynlik davranışı puanları, planlayarak gebe kalan kadınlarınkinden daha düşüktü. Anne olma süreci yoğun psikolojik, sosyal ve fiziksel hazırlık ve ayrıca çalışmayı gerektirir (14). Gebelik planlanmadığında ya da anne-baba olmaya hazır olunmadığında gebelik ve ebeveynlik rolüne uyum daha güç olmaktadır. Anne olmaya hazır ve planlayarak gebe kalan kadınlar doğum sonrası bebekleriyle daha olumlu ilişki kurabilirler. Doğum sonrası ilk dakikalar, ilk saatler ve ilk günler anne ile bebeğin yeni durumlarına uyumları ve aralarındaki ilişkiyi geliştirme yönünden önemli bir dönemdir (12,21). Gebeliğin istenmiş ve/veya planlanmış olması, bebeğin doğumdan hemen sonra çıplak bir şekilde anneyle kucaklaşmasının sağlanması ve ikisi arasındaki yakın beden temasının sağlanması olumlu annelik davranışını ve anne-bebek ilişkisini destekler (17,22,23). Yapılan çalışmalarda, planlamadan gebe kalan kadınlar ile bebekleri arasındaki etkileşimin, planlayarak gebe kalan kadınlarınkinden daha yetersiz olduğu, eğitim düzeyinin, algılanan aile gelir durumunun, gebelik sayısının ve aile-bebek bağlarını güçlendiren yöntemlerin hepsinin, anne-bebek etkileşimini etkilediği bildirilmiştir $(10,24,25)$.Yapılan bir çalışmada kadınların gebeliği planlama durumlarına göre doğum sonrası erken dönemdeki annelik davranışı arasında anlamlı 
bir ilişki olduğu, planlayarak gebe kalan kadınların davranış puanlarının yüksek olduğu bildirilmiştir (26). Bu çalışmada da gebeliğin planlanma durumunun annelik davranışı puanını etkilediği, planlayarak gebe kalan kadınların annelik davranış puanlarının yüksek olduğu, diğer bir deyişle bebeklerine olumlu annelik davranışı gösterdikleri saptandı. Buna göre gebeliğin planlanmış ya da planlanmamış olması, annelik davranışı ile ilişkili önemli bir faktör olarak gösterilebilir. Planlayarak gebe kalan kadınların kendilerini anneliğe hazır hissetmeleri DSEDÖ puanının yüksek olmasında etkili olmuş olabilir.

$\mathrm{Bu}$ çalışmada planlamadan gebe kalmanın doğum sonrası erken dönemdeki annelik davranışına etkisi araştırılmak istendi. Fakat eşlik eden bazı sosyo-demografik ve doğuma ilişkin faktörlerin de annelik davranışı ile ilişkili rolünün olabileceği düşünüldü. $\mathrm{Bu}$ nedenle planlamadan gebe kalmanın diğer faktörler kontrol altına alındıktan sonra doğum sonrası erken dönemdeki annelik davranışına etkisinin olup olmadığ 1 ve ne kadar etki ettiğinin bilinmesine gereksinim duyuldu. İstatistiksel olarak annelik davranış puanları bakımından anlamlı farklılık saptanan faktörler, gebeliğin planlanma durumu ile birlikte çoklu linear regresyon analizine alındı. Bu faktörler kadınların yaşı, eğitim düzeyi, eşlerin çalışma durumu, gelir düzeyi, aile tipi, canlı doğum sayısı, gebelikte problem yaşama ve doğum öncesi bebek bakımıyla ilgili bilgi alma durumuydu. Buna göre diğer faktörler kontrol altına alındıktan sonra gebeliğin planlanma durumunun, canlı doğum sayısının, gelir düzeyinin ve doğum öncesi bebek bakımı ile ilgili bilgi alma durumunun doğum sonrası erken dönemde kadınların bebeklerine gösterdikleri annelik davranışı ile ilişkili faktörler olduğu belirlendi. Böylece bu çalışmada gebeliğin planlanmamış olmasının yanında kadınların doğum sonu erken dönemde annelik davranışı ile ilişkili olabilecek diğer birçok faktörün de rolünün olabileceği gösterildi.

\section{Sinırlılıklar}

$\mathrm{Bu}$ araştırmanın bazı sınırlılıkları bulunmaktadır. Birincisi, kadınlara araştırmaya katılmayı isteyip istemedikleri ve araştırma ile ilgili açıklamalar, doğum sonrası erken dönemdeki annelik davranışı gözlenmeden önce yapıldığı için bu durum, kadınların bebeklerine gösterdikleri davranışları etkilemiş olabilir. İkincisi, örneklem grubuna alınacak kadınların yaş aralığ1 18-35 yaş olarak planlandığı için daha genç ve ileri yaş kadınlar araştırmaya alınmadı, bu durum araştırma sonuçlarını etkilemiş olabilir. Üçüncüsü, vaka ve kontrol grubuna alınan kadınlar randomize olarak seçilemedi. Bu nedenle gebeliğin planlanmış ya da planlanmamış olması dışındaki diğer bağımsız değişkenler kontrol altına alınamadı. Bu durumda vaka ve kontrol grupları arasında diğer bağımsız değişkenler bakımından homojenlik sağlanamadı. Yine de bu çalışmada yapılan regresyon analizi sonucunda planlanmamış gebeliğin doğum sonrası erken dönemdeki kadınların ilk annelik davranışını etkileyen en önemli faktör olduğu ortaya konuldu.

\section{SONUÇ VE ÖNERİLER}

$\mathrm{Bu}$ çalışmada planlamadan gebe kalan kadınlar ile planlayarak gebe kalan kadınlar arasında doğum sonrası ilk karşılaşmada bebeklerine gösterdikleri ebeveynlik davranışı bakımından önemli fark vardı. Planlayarak gebe kalan kadınlar doğum sonrası erken dönemde bebeklerine karşı daha olumlu ebeveynlik davranışı gösterirken, planlamadan gebe kalan kadınlar daha olumsuz ebeveynlik davranışı gösterdiler. Gebeliğin planlanmamış olması 
doğum sonrası erken dönemdeki ebeveynlik davranışını olumsuz etkileyen önemli bir faktördür. Çalışma sonucunda kadınların planlamadan gebe kalması, canlı doğum sayısının fazla olması, gelirinin giderden az olması ve doğum öncesi bebek bakımı ile ilgili bilgi almamış olması, kadınların doğum sonrası erken dönemdeki annelik davranışlarını olumsuz etkileyen faktörler olarak bulundu. $\mathrm{Bu}$ çalışmadan elde edilen sonuçlar doğrultusunda, ebe ve hemşirelerin kadınlara ve eşlerine, istedikleri zaman ve bakabilecekleri sayıda çocuk sahibi olmaları için planlı gebelik konusunda gerekli danışmanlık vermeleri önerilir. Ebe ve hemşireler tarafından, doğum sonrası erken dönemde annelik davranışı ile ilişkili risk faktörlerinin bilinmesi, annelerin gereksinimlerinin belirlenmesi ve özellikle planlamadan gebe kalan kadınların ebeveynliğe uyumlarının desteklenmesi önemlidir. Ayrıca ebe ve hemşireler, doğum sayısı fazla olan, gelir düzeyi düşük olan ve doğum öncesi bebek bakımıyla ilgili bilgi almamış olan kadınlara daha fazla zaman ayırabilir ve destek olabilirler.

\section{Araştırmanın Etik Yönü}

Adnan Menderes Üniversitesi Tıp Fakültesi Girişimsel Olmayan Klinik Araştırmalar Etik Kurulu Başkanlığı'ndan, yapılan araştırmanın etik ilkelere uygun olduğuna ilişkin onay alındı (Protokol no: 2012/93). Araştırmanın yapıldığ alındı. Kadınlara araştırma amaç ve yöntemi hakkında açıklama yapıldıktan sonra katılmayı kabul eden kadınlardan yazılı onam alındı.

\section{Çıkar çatışması}

Yazarlar arasında çıkar çatışması yoktur.

\section{Teşekkür}

$\mathrm{Bu}$ araştırmaya katılan kadınlara teşekkür ederiz.

\section{KAYNAKLAR}

1. Guttmacher Institute. (2018). Unintended pregnancy rates declined globally from 1990 to 2014. https://www.guttmacher.org/news-release/2018/unintended-pregnancy-ratesdeclined-globally-1990-2014 (Erişim tarihi: 29 Eylül 2019).

2. Sedgh, G., Singh, S., \& Hussain, R. (2014). Intended and unintended pregnancies worldwide in 2012 and recent trends. Stud Fam Plann, 45(3), 301-314.

3. Wellings, K., Jones, K. G., Mercer, C. H., Tanton, C., Clifton, S., Datta, J., et al. (2013). The prevalence of unplanned pregnancy and associated factors in Britain: findings from the third National Survey of Sexual Attitudes and Lifestyles (Natsal-3). Lancet 382(9907), 1807-1816.

4. Sisay, A., Asres, N., \& Tesfaye, S. (2019). Prevalence of unplanned pregnancy and factor among pregnant women, Ethiopia 2018 GC. Clinical Medicine Research, 8(2),3946.

5. Hacettepe Üniversitesi Nüfus Etütleri Enstitüsü. (2014). Türkiye Nüfus ve Sağlık Araştırmas1 2013. (ss.115-128). Hacettepe Üniversitesi Nüfus Etütleri Enstitüsü, TC Kalkınma Bakanlığı ve TÜBİTAK, Ankara, Türkiye. 
6. Hacettepe Üniversitesi Nüfus Etütleri Enstitüsü. (2019). Türkiye Nüfus Sağlık Araştırmas1 2018. (ss.70-82). Hacettepe Üniversitesi Nüfus Etütleri Enstitüsü, TC Cumhurbaşkanlığ 1 Strateji ve Bütçe Başkanlığı ve TÜBİTAK, Ankara, Türkiye.

7. Yanikkerem, E., Ay, S., \& Piro, N. (2013). Planned and unplanned pregnancy: Effects on health practice and depression during pregnancy. J Obstet Gynaecol Res, 39(1), 180 187.

8. Ersoy, E., Karasu, Y., Çelik, E., Ersoy, A., Tokmak, A., \& Taşçı, Y. (2015). Gebeliği plansız olan kadınların kişisel özellikleri ve kontrasepsiyon hakkındaki düşünceleri (Individual features and contraceptive attitudes of women who had unintended pregnancy). Journal of Clinical and Experimental Investigations, 6(3), 250-255.

9. Tekiner, A. S., Çetin, F., Ceyhun, G., \& Kafkasl1, A. (2010). Planlanmamış gebelikler ile kontraseptif yöntemler arasındaki ilişki. Dirim Tıp Gazetesi, 85(2), 65-71.

10. Karaçam, Z., Şen, E., \& Amanak, K. (2010). Effects of unplanned pregnancy on neonatal health in Turkey: A case-control study. Int J Nurs Pract, 16(6), 555-563.

11. Tsegaye, A. T., Mengistu, M., \& Shimeka, A. (2018). Prevalence of unintended pregnancy and associated factors among married women in west Belessa Woreda, Northwest Ethiopia, 2016. Reprod Health, 15(201),1-8.

12. Beydağ, K. D. (2007). Doğum sonu dönemde anneliğe uyum ve hemşirenin rolü. TSK Koruyucu Hekimlik Bülteni, 6(6), 479-484.

13. Karaçam, Z., Önel, K., \& Gerçek, E. (2011). Effects of unplanned pregnancy on maternal health in Turkey. Midwifery, 27(2), 288-293.

14. Mercer, R. T. (2004). Becoming a mother versus maternal role attainment. $J$ Nurs Scholarsh, 26(3), 226-232.

15. Çalışır, H., Karaçam, Z., Akgül, F. A., \& Kurnaz, D. A. (2009). Doğum sonrası ebeveynlik davranışı ölçeğinin Türkçe formunun geçerliği ve güvenirliği. Atatürk Üniversitesi Hemşirelik Yüksekokulu Dergisi, 12(1), 1-8.

16. Çalışır, H., \& Başbakkal, Z. (2003). İlk kez anne olan kadınların annelik rolü başarımlarını etkileyen etmenlerin incelenmesi. Yayınlanmamış Doktora Tezi. Ege Üniversitesi Sağlık Bilimleri Enstitüsü, İzmir, Türkiye.

17. Çalışır, H., \& Karaçam, Z. (2011). Factors associated with parenting behavior of mothers in the early postpartum period in Turkey. Nursing and Health Sciences, 13(4), 488-494.

18. Britton, H. L., Gronwaldt, V., \& Britton, J. R. (2001). Maternal postpartum behavior and mother-infant relationship during the first of life. J Pediatr, 138, 905-909.

19. Akgül, A. (2005). Tıbbi Araştırmalarda İstatistiksel Analiz Teknikleri "SPSS Uygulamaları". (ss. 187-403). Ankara: Emek Ofset.

20. Burns, N., \& Grove, S. K. (2001). The Practice of Nursing Research (4th ed). Philadelphia: Saunders Company.

21. Yıldırım, G., \& Gökyıldız, Ş. (2004). Sağlıklı bebeğe sahip olamayan ailelerin yaşadığ psikososyal sorunlar. Atatürk Üniversitesi Hemşirelik Yüksekokulu Dergisi, 7(3), 74-82.

22. Kennell, J., \& Mcgrath, S. (2005). Starting the process of mother-infant bonding. Acta Pediatrica, 94(6), 775-777

23. Kavlak, O., \& Şirin, A. (2009). Maternal bağlanma ölçeğinin Türk toplumuna uyarlanmas1. Uluslararası Insan Bilimleri Dergisi, 6(1), 188-202.

24. Çoban, A. (2003). Doğum sonrası anne-yenidoğan etkileşimini etkileyen bazı etmenlerin incelenmesi. Yüksek Lisans Tezi. Ege Üniversitesi Sağlık Bilimleri Enstitüsü, İzmir, Türkiye.

25. Çoban, A., \& Saruhan, A. (2005). Anne-bebek etkileşiminde hemşirenin rolü. Ege Üniversitesi Hemşirelik Yüksekokulu Dergisi, 21(2), 89-96. 
Adnan Menderes Üniversitesi Sağlık Bilimleri Fakültesi Dergisi 2021: 5(1); 37-50

Journal of Adnan Menderes University Health Sciences Faculty

26. Özkan, H., Kanbur, A., Apay, S., Kılıç, M., Ağapınar, S., \& Özorhan, E. Y. (2013). Annelerin doğum sonu dönemde ebeveynlik davranışlarının değerlendirilmesi. Şişli Etfal Hastanesi Tıp Bülteni, 47(3), 117-121. 